\title{
Implementasi Undang-Undang Nomor 21 Tahun 2019 Tentang Karantina Hewan, Ikan Dan Tumbuhan Pada Balai Besar Karantina Pertanian Belawan
}

\section{Implementation of Law Number 21 of 2019 concerning Animal, Fish and Plant Quarantine at the Belawan Agricultural Quarantine Center}

\author{
Hotma Diana Siregar, Maksum Syahri Lubis \& Adam* \\ Program Studi Magister Ilmu Administrasi Publik, Universitas Medan Area, Indonesia
}

Diterima: 27 Juni 2021; Disetujui: 15 Desember 2021; Dipublish: 01 Januari 2022

\begin{abstract}
Abstrak
Penelitian ini bertujuan untuk menganalisis implementasi kebijakan karantina tumbuhan pada satuan kerja Balai Besar Karantina Pertanian Belawan. Penelitian ini menggunakan pendekatan kualitatif dimana peneliti adalah sebagai instrumen kunci, teknik pengumpulan data dilakukan secara trangulasi (observasi, wawancara dan dokumentasi), data yang diperoleh cenderung data kualitatif, analisis data bersifat kualitatif dan hasil penelitian kualitatif bersifat untuk memahami makna dan mengkonstruksi fenomena implementasi kebijakan peraturan pelayanan karantina tumbuhan. Hasil penelitian menunjukkan bahwa implementasi kebijakan peraturan pelayanan karantina tumbuhan belum dapat terlaksana dengan optimal walaupun kebijakan peraturan undangundang yang ditetapkan sudah diberlakukan. Hal ini disebabkan oleh kurang nya komunikasi atau penyebaran informasi tentang karantina ke seluruh masyarakat khususnya para pengguna jasa. Disamping itu indikator lain disebabkan kurangnya para pegawai PNS petugas lapangan di Balai Besar Karantina Pertanian Belawan dan masih kurangnya teknologi yang menunjang untuk pelayanan di Balai Besar Karantina Pertanian Belawan.

Kata Kunci: Implementasi; Kebijakan; Pelayanan; Balai Besar Karantina Pertanian
\end{abstract}

Abstract

This study aims to analyze the implementation of plant quarantine policies in the work unit of the Belawan Agricultural Quarantine Center. This study uses a qualitative approach where the researcher is the key instrument, the data collection technique is trangulation (observation, interviews and documentation), the data obtained tends to be qualitative data, the data analysis is qualitative and the results of qualitative research are to understand the meaning and construct the phenomenon of policy implementation. plant quarantine service regulations. The results of the study indicate that the implementation of the policy on plant quarantine service regulations has not been able to be carried out optimally even though the stipulated legal regulations have been enforced. This is due to the lack of communication or dissemination of information about quarantine to the entire community, especially service users. Besides, other indicators are due to the lack of civil servant field officers at the Belawan Agricultural Quarantine Center and the lack of technology that supports services at the Belawan Agricultural Quarantine Center.

Keywords: Implementation; Policy; Service; Agricultural Quarantine Center

How to Cite: Siregar, H.D., Lubis, M.S., \& Adam. (2022). Implementasi Undang-Undang Nomor 21 Tahun 2019 Tentang Karantina Hewan, Ikan Dan Tumbuhan Pada Balai Besar Karantina Pertanian Belawan, PERSPEKTIF, 11 (1): 195-204

\footnotetext{
*Corresponding author:

E-mail: adam@staff.uma.ac.id
}

ISSN 2085-0328 (Print)

ISSN 2541-5913 (online) 


\section{PENDAHULUAN}

Pada pembukaan Undang-Undang Dasar 1945 tercantum jelas cita-cita bangsa Indonesia yakni melindungi segenap bangsa Indonesia dan seluruh tumpah darah Indonesia, memajukan kesejahteraan umum dan mencerdaskan kehidupan bangsa. Artinya bahwa negara bertanggungjawab untuk memberikan perlindungan terhadap seluruh masyarakat Indonesia, agar terhindar dari berbagai bentuk ancaman, baik ancaman perang senjata dari pihak asing maupun ancaman dari berbagai jenis penyebab penyakit, sehingga setiap penduduk dapat hidup sejahtera lahir dan batin dengan memperoleh lingkungan hidup yang sehat. Hal ini secara lebih tegas lagi dinyatakan dalam pasal Pasal 28H ayat (1) UUD 1945 yang menyatakan bahwa setiap orang berhak hidup sejahtera lahir dan batin, bertempat tinggal, dan mendapatkan lingkungan hidup yang baik dan sehat serta berhak memperoleh pelayanan kesehatan.

Salah satu bentuk ancaman kesehatan masyarakat adalah penyebaran dan perkembangan hama dan penyakit hewan, hama dan penyakit ikan dan organisme pengganggu tumbuhan. Dalam kebanyakan kasus, hama dan penyakit tersebut datang dari wilayah atau negara lain, yang kemudian berkembang di suatu daerah, kemudian mengganggu kehidupan hewan, ikan dan tumbuhan setempat, yang selanjutnya mengganggu kesehatan masyarakat. Banyak dari hewan, ikan dan tumbuhan tesebut merupakan makanan manusia, atau paling tidak akrab atau dekat dengan kehidupan manusia sehari-hari, sehingga dapat membahayakan kesehatan masyarakat.

Di Indonesia, pemerintah telah menerbitkan kebijakan karantina sebagaimana diatur dalam UU No. 21 Tahun 2019 tentang Karantina Hewan, Ikan dan Tumbuhan (UU KHIT). Pada pasal 33 dinyatakan bahwa setiap orang yang memasukkan media pembawa ke dalam wilayah RI harus melengkapi sert kesehatan hewan, ikan dan tumbuhan ( $\mathrm{n}$ pembawa) dari negara asal, memasu .мим. media pembawa melalui tempat pemasukan yang ditetapkan, serta melaporkan dan menyerahkan media pembawa kepada pejabat karantina. Sedangkan tindakan karantina yang dilakukan oleh pejabat karantina antara lain adalah tindakan pemeriksaan, pengasingan dan pengamatan, perlakuan, penahanan, penolakan, pemusnahan, ataupun pembebasan, tergantung pada hasil pengamatan dan keputusan pejabat karantina.

Balai Besar Karantina Pertanian Belawan merupakan unit pelaksana teknis dibidang perkarantinaan hewan dan tumbuhan yang berada dibawah dan bertanggungjawab kepada Kepala Badan Karantina Pertanian. Adapun tempat pelayanan Balai Besar Karantina Pertanian Belawan adalah di Pelabuhan Laut Belawan, Pelabuhan Laut Sibolga. Balai Besar Karantina Pertanian Belawan telah berupaya mengimplementasikan UU Perkarantinaan, namun kenyataan nya implementasinya belum berjalan dengan baik. Permasalahan yang ada di Balai Besar Karantina Pertanian Belawan, Pada hari Senin Tanggal 29 Januari 2018 sekitar pukul 17.00 waktu Thailand KM. Akarasa berangkat dari pelabuhan Satun Thailand menuju ke Pelabuhan Air Masin Kabupaten Aceh Tamiang Provinsi NAD Indonesia. Pada hari Selasa tanggal 30 Januari 2018 sekitar pukul 19.00 Wib di Perairan Teritorial Selat Malaka, KM. Akarasa dihentikan oleh satuan TNI-AL yang beroperasi, adapun KM. Akarasa membawa muatan berupa beras ketan sebanyak 25 ton, dikarenakan Nahkoda tidak dapat menunjukan dokumen-dokumen yang dibutuhkan maka dari itu kapal tersebut diamankan dan dibawa ke Lantamal I Belawan. TNI AL Belawan bekerja sama dengan tim Bidang Pengawasan dan Penindakan Karantina Belawan berhasil menggagalkan upaya penyelundupan 20 ton beras ketan asal Thlailand di perairan teritorial Belawan. "Modus operandinya, beras disimpan dalam palka kapal," kata Agus Sunanto selaku Kepala Balai Besar Karantina Pertanian Belawan. "Upaya

penggagalan penyelundupan komoditas pertani an merupakan keberhasilan bersama dalam menyelamatkan negara dari kerugian serta adanya penyakit tumbuhan yang punya potensi merusak sektor pertanian yang bisa merugikan petani kita," ujar Agus Sunanto Sebagai Kepala Balai Besar Karantina Pertanian Belawan. Saat ini, beras ilegal telah dipindahkan dari palka Kapal KM Akarasa ke gudang Karantina Pertanian Belawan di jalan AH Nasution Gedung Johor Medan untuk penyidikan PPNS Karantina Belawan.

Hasil penelitian Kristalia Purba (2015) dengan judul Pengawasan dan Karantina 
terhadap Tumbuhan dan Hewan Pada Balai Besar Karantina Tumbuhan dan Hewan Belawan, diperoleh bahwa sistem dan mekanisme pengawasan yang dilakukan oleh Balai Besar Karantina Tumbuhan dan Hewan Belawan terhadap tumbuhan dan hewan yang masuk dan atau keluar melalui pelabuhan Belawan adalah sebagai upaya pencegahan masuk dan tersebarnya Organisme Pengganggu Tumbuhan (Hama dan Penyakit Tumbuhan) dan hewan dari luar negeri dan dari suatu Area ke Area lain di dalam negeri atau keluar nya dari dalam wilayah Negara Republik Indonesia. Hambatan yang dihadapi Balai Besar Karantina Pertanian Belawan dalam pelaksanaan pengawasan dan penindakan karantina khusus nya tumbuhan yang masuk dan atau keluar melalui pelabuhan Belawan disebabkan pelaku usaha masih mengabaikan proses sertifikasi Balai Besar Karantina Tumbuhan Belawan. Pelaku usaha tidak serius melengkapi sertifikasi yang diminta negara tujuan. Tanpa kelengkapan itu produk mereka tidak akan bisa diterima. Pengusaha ingin mengambil keuntungan sebesar-besarnya dengan mengabaikan sertifikasi. Berdasarkan kesimpulan maka disarankan agar proses pelaksanaan pengawasan karantina khususnya terhadap tumbuhan yang masuk dan atau keluar melalui pelabuhan Belawan hendaknya tersedia aparat dan sarana serta prasarana yang mendukung lancarnya proses pengawasan dimaksud. Agar hasil dari proses pengawasan dimaksud dapat direalisasikan hendaknya perlu dipikirkan tindak lanjut dari proses pengawasan dan juga agar tekanan tekanan yang ditujukan kepada pihak yang diberi wewenang memeriksa dikurangi, sehingga pada akhirnya proses pengawasan dimaksud lambat laun dapat diperlonggar seiring dengan makin terciptanya aparatur negara yang bersih dan berwibawa.

Hasil penelitian Abdul Munif (2012) dengan judul Perspektif dan Inisiatif Pengembangan Perlakuan Karantina Tumbuhan, diperoleh hasil bahwa perdagangan komoditas pertanian antar negara memberikan dampak positif bagi perolehan devisa dan pembangunan perekonomian suatu negara. Pada sisi lain, disadari atau tidak perdagangan komoditi pertanian antar negara juga memiliki risiko terhadap berpindahnya organisme pengganggu tumbuhan (OPT) dari suatu negara ke negara lain melalui komoditas pertanian/ media pembawa yang diperdagangkan. Meningkatnya arus komoditi, terutama ke dan dari negara yang ekonominya cepat (rapidly developing economies) dengan perbatasan antar wilayah Indonesia yang lemah (porous borders) dan land borders ditambah dengan semakin tingginya informal and traditional trade, kebijakan/komitmen yang kuat terhadap 'economic integration, lemahnya regulasi dibidang lingkungan, terbatasnya kapasitas tenaga teknis petugas Karantina Pertanian dan masih lemahnya rencana pengembangan kerjasama antar lembaga perkarantinaan serta lemahnya komitmen pihak swasta terhadap masalah OPT akan menambah resiko masuknya OPT ke wilayah Indonesia semakin besar. Hal ini mengharuskan perlunya terus memperkuat perkarantinaan nasional baik secara kelembagaan maupun kemampuan profesionalitas sumberdayanya.

Hasil penelitian Gusti Ngurah Suartono (2016) dengan judul Kualitas Pelayanan Karantina Hewan pada Kantor Balai Karantina Pertanian Kelas II Palu, Wilayah Kerja Bandar Mutiara Sis Al Jufri Palu, diperoleh bahwa di ruang pelayanan karantina hewan Kantor Balai Karantina Pertanian Kelas II Palu Wilayah Kerja Bandara Mutiara Sis Al Jufri Palu, bahwa kualitas pelayanan yang ditemukan berdasarkan variabel yang digunakan untuk mengukur kualitas pelayanan terdiri dari Tangibles, Realibility, Responsiveness, Assurance dan Emphaty secara keseluruhan sudah memenuhi standar kualitas dari variabelvariabel tersebut. Kualitas pelayanan karantina hewan pada kantor Balai Karantina Pertanian Kelas II Palu Wilayah Kerja Bandara Mutiara Sis Al Jufri Palu, dapat dilihat dan dirasakan secara langsung seperti tersedianya gedung dan bangunan untuk ruang pelayanan dengan peralatan-peralatan pendukung, kemampuan petugas dalam standar dan prosedur pelayanan yang benar serta kemauan petugas untuk memberikan pelayanan dengan cepat, mudah, transparan dan penuh dengan kesopanan dan keramahan sebagai wujud dari kepedulian (emphati).

Hasil penelitian Bazar Ristiyawan (2013) dengan judul Peranan Implementasi Kebijakan Karantina Ikan dalam Pembangunan Perikananan Berkelanjutan, diperoleh bahwa Pokok-pokok kebijakan karantina ikan sejalan 
dengan prinsip-prinsip kelestarian sumberdaya alam perikanan, terutama terhadap upaya konservasi melalui upaya preventif dan pengendalian terhadap HPIK. Dengan ikut berperan dalam menjaga sumberdaya alam agar tetap lestari dan dapat dimanfaatkan oleh generasi pada saat ini dan akan tetap terjaga sampai generasi yang akan datang, maka telah ikut mewujudkan salah satu prinsip pembangunan keberlanjutan yaitu keadilan antar generasi dan memenuhi prinsip keberlanjutan ekologi.

Hasil penelitian Nely Zubaedah (2015) dengan judul Keefektifan Kebijakan Pembatasan Pintu Masuk Impor Hortikultura terhadap Aspek Perlindungan Tanaman, diperoleh bahwa kebijakan pembatasan pintu masuk ternyata belum cukup efektif dalam mencegah masuknya Organisme Pengganggu Tumbuhan Karantina (OPTK) baru kedalam wilayah Indonesia. Hal tersebut didasarkan pada temuan Alternaria citri dan Fusarium incarnatum yang belum pernah dilaporkan terdapat di Indonesia dan ditemukan pada komoditas hortikultura yang masuk melalui salah satu pintu masuk yang ditetapkan yaitu pelabuhan laut Tanjung Perak, Jawa Timur. Oleh karena itu, pemerintah perlu segera melakukan evaluasi dan penguatan kelembagaan di wilayah yang ditunjuk sebagai pintu pemasukan impor.

\section{METODE PENELITIAN}

Penelitian dilakukan pada Kantor Balai Besar Karantina Pertanian Belawan, di Jalan Sulawesi II Ujung Baru Belawan Kota Belawan Medan. Penelitian ini menggunakan metode deskriptif kualitatif, yaitu prosedur pemecahan masalah yang diselidiki dengan menggambarkan keadaan subjek/objek penelitian pada saat sekarang berdasarkan fakta yang tampak. Menurut Sugiyono (2012), "Penelitian deskriptif yaitu jenis penelitian yang memberikan gambaran atau uraian suatu keadaan pada objek yang diteliti. Data yang terkumpul akan dianalisa secara kualitatif".

Penelitian kualitatif tidak dimaksudkan untuk membuat generalisasi dari hasil penelitiannya. Menurut Suyatno (2010) bahwa informan penelitian meliputi beberapa macam, yaitu: 1) informan kunci merupakan mereka yang mengetahui dan memiliki berbagai informasi pokok yang diperlukan dalam penelitian, 2) informan utama merupakan mereka yang terlibat langsung dalam interaksi sosial yang diteliti, 3) informan tambahan merupakan mereka yang dapat memberikan informasi walaupun tidak langsung terlibat dalam interaksi sosial yang diteliti.

Dalam penelitian ini, penulis menggunakan informan kunci yaitu Kepala Balai Besar Karantina Pertanian Belawan, informan utama yaitu Kepala Bidang Karantina Tumbuhan dan informan tambahan yaitu Kepala Seksi Pelayanan Operasional Karantina Tumbuhan dan Pengusaha (Pengguna Jasa Karantina Tumbuhan).

Untuk memperoleh data atau informasi yang mendukung tujuan penelitian, penulis menggunakan metode pengumpulan data primer dan sekunder. Teknik Pengumpulan Data Primer, yaitu : Wawancara, yaitu peneliti melakukan wawancara secara mendalam (indepht interview) dengan narasumber (informan) dengan berpedoman pada interview-guidances yang telah disusun sebelumnya. Pemberian pertanyaan kepada subjek penelitian. Dilakukan secara terbuka dan fleksibel sesuai dengan perkembangan yang terjadi selama proses wawancara. Observasi, yaitu pengamatan secara langsung yang dilakukan peneliti di lokasi penelitian untuk melihat kenyataan dan fakta sosial sehingga dapat dicocokkan antara hasil wawancara atau informasi dari subjek penelitian secara langsung yang digunakan untuk mendapatkan data tentang Implementasi Undang-Undang No. 21 Tahun 2019 tentang Karantina Hewan, Ikan, dan Tumbuhan Pada Balai Besar Karantina Pertanian Belawan (Study Karantina Tumbuhan).

Teknik Pengumpulan Data Sekunder, yaitu: Dokumentasi, yaitu teknik pengumpulan data dengan menggunakan catatan-catatan atau dokumen yang ada di lokasi penelitian serta sumber-sumber lain yang relevan dengan objek penelitian. Studi kepustakaan, yaitu teknik pengumpulan data dengan menggunakan berbagai literatur seperti buku, karya ilmiah, pendapat para ahli yang berhubungan dengan masalah yang diteliti.

Analisa data adalah proses penyederhanaan data ke dalam bentuk yang lebih mudah dibaca dan diinterprestasikan. Analisa data dilakukan setelah proses pengumpulan data diperoleh untuk mengetahui Implementasi Undang-Undang No. 21 Tahun 2019 tentang Karantina Hewan, Ikan, 
dan Tumbuhan Pada Balai Besar Karantina Pertanian Belawan (Study Karantina Tumbuhan). Analisa data yang digunakan adalah bersifat deskriptif, yakni menggambarkan keadaan status fenomena. Dari analisa data ini mempunyai tujuan diantaranya sebagai berikut: Data dapat diberikan makna yang berguna dalam memecahkan masalah-masalah penelitian. Memperlihatkan hubungan-hubungan antara fenomena yang diajukan dalam penelitian. Untuk memberikan jawaban terhadap masalah yang diajukan dalam penelitian. Bahan untuk membuat kesimpulan serta implikasi-implikasi dan saran-saran yang berguna untuk kebijakan penelitian. Setelah semua data terkumpul kemudian diolah atau dianalisis secara deduksi, yaitu pengelolaan data dengan menyimpulkan dari data yang bersifat umum kemudian disimpulkan menjadi khusus.

\section{HASIL DAN PEMBAHASAN \\ Implementasi Undang-Undang No. 21 Tahun 2019 tentang Karantina Hewan, Ikan, dan Tumbuhan Pada Balai Besar Karantina Pertanian Belawan}

Komunikasi. Implementasi harus didahului dengan sosialisasi tentang kebijakan kepada semua pihak yang berkaitan. Sosialisasi tersebut dilaksanakan melalui serangkaian proses komunikasi, yaitu penyampaian informasi tentang isi kebijakan, baik komunikasi langsung maupun komunikasi melalui media.

Komunikasi kebijakan dikatakan berhasil apabila disampaikan melalui saluran komunikasi yang tepat (transmisi), maksud kebijakan disampaikan secara jelas, serta terdapat konsistensi atas kebijakan yang disampaikan dalam arti tidak berubah-ubah. Berikut ini akan dibahas mengenai bagaimana proses komunikasi kebijakan kebijakan karantina tumbuhan dalam UU No. 21 Tahun 2019, yang terdiri dari transmisi, konsistensi dan kejelasan.

Transmisi. Penyampaian kebijakan Karantina Tumbuhan harus dilakukan melalui jenis komunikasi yang mampu menyampaikan maksud kebijakan secara tepat kepada pihak yang terkait, khususnya kepada para implementor, yang dalam hal ini adalah para pegawai Balai Besar Karantina Pertanian Belawan. Pada umumnya penyampaian informasi tersebut dapat dilakukan langsung oleh atasan maupun melalui media komunikasi. Implementasi kebijakan, sehingga pimpinan selalu memberikan informasi yang tepat kepada bawahan mengenai kebijakan Karantina Tumbuhan yang akan diimplementasikan. Dengan demikian dapat disimpulkan bahwa bahwa penyampaian kebijakan oleh atasan telah cukup mendukung proses implementasi UU No. 21 Tahun 2019 dalam meningkatkan pelayanan karantina tumbuhan pada Balai Besar Karantina Pertanian Belawan.

Kebijakan Karantina Tumbuhan juga melibatkan pihak lain seperti instansi lain seperti pelaku usaha, sehingga sosialisasi kepada pihak eksternal harus dilakukan.

Dari hasil wawancara di atas dapat dijelaskan bahwa instansi telah melakukan sosialisasi Karantina Tumbuhan kepada pihak lain yang berkepentingan. Sosialisasi tersebut dilakukan dengan pemberitahuan secara langsung maupun dengan membuat spanduk. Disamping itu penyebaran informasi juga dilakukan secara langsung kepada para pengguna jasa karantina, terutama kepada para pengusaha yang berkepentingan. Dengan demikian dapat disimpulkan bahwa sosialisasi kebijakan telah dilakukan dengan baik sehingga cukup mendukung proses impelementasi UU No. 21 Tahun 2019 dalam meningkatkan pelayanan karantina tumbuhan pada Balai Besar Karantina Pertanian Belawan.

Pembahasan mengenai implementasi Karantina Tumbuhan dilakukan dengan membuat pertemuan resmi, yaitu dengan membahas berbagai hal yang diperlukan dalam implementasi kebijakan. Dalam pertemuan tersebut semua pegawai secara aktif melakukan pembahasan mengenai kebijakan penerapan Karantina Tumbuhan, mengingat kebijakan tersebut masih tergolong baru. Dengan demikian pertemuan untuk membahas kebijakan telah dilakukan dengan baik sehingga cukup mendukung proses impelementasi UU No. 21 Tahun 2019 dalam meningkatkan pelayanan karantina tumbuhan pada Balai Besar Karantina Pertanian Belawan. Kejelasan. Komunikasi dalam implementasi Karantina Tumbuhan sesuai dengan UU No. 21 Tahun 2019 harus dapat memberi kejelasan tentang maksud dari kebijakan, sehingga tidak menimbulkan kekeliruan dalam penerapannya. 
Dari hasil wawancara di atas dapat dijelaskan bahwa dalam setiap penyampaian kebijakan Karantina Tumbuhan, atasan telah memberikan penjelasan yang memadai, yaitu penjelasan mengenai teknis pelaksanaannya, sehingga semua pegawai dapat memahami secara lebih jelas mengenai apa yang harus dilakukan dan siapa yang melakukannya. Dengan demikian dapat disimpulkan bahwa peran atasan memberi penjelasan mengenai teknis pelaksanaan kebijakan telah cukup mendukung proses impelementasi UU No. 21 Tahun 2019 dalam meningkatkan pelayanan karantina tumbuhan pada Balai Besar Karantina Pertanian Belawan.

Kejelasan suatu kebijakan juga sangat tergantung pada kemampuan komunikasi atasan dalam memberi penjelasan, sehingga dapat memberi penjelasan yang memadai, yang berarti akan memudahkan pemahaman bagi pegawai yang terkait dengan implementasi Karantina Tumbuhan. Artinya bahwa pimpinan pada instansi selalu mampu memilih gaya komunikasi dan bahasa yang tepat dalam memberi arahan, agar apa yang disampaikan mudah dimengerti sesuai dengan maksud kebijakan. Dengan demikian gaya komunikasi atasan dalam memberi penjelasan tentang kebijakan telah cukup mendukung proses impelementasi UU No. 21 Tahun 2019 dalam meningkatkan pelayanan karantina tumbuhan pada Balai Besar Karantina Pertanian Belawan.

Konsistensi. Yang dimaksud dengan konsistensi bahwa implementor harus memiliki pemahaman yang sama terhadap kebijakan, agar kebijakan tersebut dapat diterapkan secara konsisten sebagaimana seharusnya menurut kebijakan.

Dari hasil wawancara dapat dijelaskan bahwa semua pegawai telah memiliki kesamaan pemahaman atas kebijakan Karantina Tumbuhan sesuai dengan maksud yang terkandung dalam kebijakan. Pada awalnya penafsiran yang berbeda terhadap kebijakan tentu saja bisa terjadi, tetapi hal tersebut selalu dapat diatasi melalui proses diskusi, sehingga dapat membentuk pemahaman bersama atas kebijakan yang dimplementasikan. Dengan demikian pemahaman bersama terhadap kebijakan telah cukup mendukung proses impelementasi UU No. 21 Tahun 2019 dalam meningkatkan pelayanan karantina tumbuhan pada Balai Besar Karantina Pertanian Belawan.
Beberapa hal yang dilaporkan dapat diatasi dengan baik, tetapi terdapat juga kendala lapangan yang tidak berhasil diatasi, sehingga menimbulkan pemecahan masalah yang kurang sejalan dengan kebijakan yang diimplementasikan. Dengan demikian dapat disimpulkan bahwa upaya mengatasi kendala lapangan masih tergolong kurang memadai sehingga tidak mendukung proses impelementasi UU No. 21 Tahun 2019 dalam meningkatkan pelayanan karantina tumbuhan pada Balai Besar Karantina Pertanian Belawan.

Sumber Daya. Implementasi kebijakan harus didukung oleh ketersediaan sumber daya, yaitu segala sesuatu yang terdapat pada organisasi, baik sumberdaya fisik maupun sumber daya non fisik. Sering terjadi bahwa sumber daya yang tidak tersedia menyebabkan implementasi tidak dapat dilakukan dengan baik sehingga maksud dari pembuat kebijakan menjadi tidak dapat dicapai sebagaimana mestinya.

Indikator yang digunakan untuk mengetahui dukungan sumber daya adalah: kompetensi SDM (pegawai), sistem informasi, program pelatihan SDM, dan ketersediaan dana. Kompentensi SDM. Kompetensi SDM yang dibutuhkan untuk implementasi Karantina Tumbuhan sesuai dengan Perbup No. 14 Tahun 2018 adalah kompetensi kerja, integritas, dan kerjasama.

Dari hasil wawancara di atas dapat dijelaskan bahwa kompetensi kerja pegawai dalam melakukan pemeriksaan terhadap bahan karantina tumbuhan telah cukup baik. Hal ini karena pegawai telah diberi pelatihan dan bimbingan teknis sebelum ditempatkan pada bidang kerjanya. Disamping itu, pegawai juga ditempatkan sesuai dengan latar belakang pendidikannya Dengan demikian kompetensi kerja pegawai dalam melakukan pemeriksaan sudah tergolong baik sehingga cukup mendukung proses impelementasi UU No. 21 Tahun 2019 dalam meningkatkan pelayanan karantina tumbuhan pada Balai Besar Karantina Pertanian Belawan.

Kompetensi kerja juga dapat dilihat dari kemampuan pegawai dalam menggunakan alat-alat atau sarana dan prasarana yang digunakan dalam pemeriksaan, khususnya alatalat laboratorium.

Dari hasil wawancara di atas dapat dijelaskan bahwa pegawai juga telah memiliki kompetensi yang baik dalam menggunakan 
alat-alat yang diperlukan dalam pemeriksaan tumbuhan, khususnya alat-alat laboratorium. Alat-alat yang dimaksud sudah sering digunakan dalam proses kerja sehari-hari, dan disamping itu terdapat semua pegawai telah mengetahui prosedur kerja dalam penggunaan alat serta prosedur kerja pemeriksaan yang harus dilakukan oleh pegawai. Dengan demikian dapat disimpulkan bahwa pegawai telah memiliki kompetensi yang cukup baik dalam penggunaan alat-alat pemeriksaan sehingga cukup mendukung proses impelementasi UU No. 21 Tahun 2019 dalam meningkatkan pelayanan karantina tumbuhan pada Balai Besar Karantina Pertanian Belawan.

Integritas pegawai dalam pelaksanaan Karantina Tumbuhan juga sangat penting. Pegawai harus dapat melakukan pekerjaan dengan mempedomani nilai-nilai pribadi yang jujur dan terpercaya. Kemampuan kerjasama pegawai juga penting untuk dapat menerapkan kebijakan Karantina Tumbuhan dengan baik.

Dapat dijelaskan bahwa pegawai pada instansi ini sudah dapat bekerjasama dengan baik, tetapi masih perlu ditingkatkan agar fungsi pelayanan menjadi lebih baik lagi kedepannya. Kerjasama yang baik dapat terlaksana karena didukung fakta bahwa sebagian besar pegawai pada instansi ini sudah lama saling mengenal satu sama lain. Disamping itu pegawai juga menyadari tugas pelayanan harus dilakukan secara terpadu sehingga kerjasama menjadi sangat penting, baik kerjasama antar pegawai dalam unit yang sama maupun dalam unit organisasi yang berbeda. Dengan demikian kemampuan kerjasama pegawai telah tergolong baik sehingga cukup mendukung proses impelementasi UU No. 21 Tahun 2019 dalam meningkatkan pelayanan karantina tumbuhan pada Balai Besar Karantina Pertanian Belawan.

Ketersediaan Dana. Implementasi kebijakan tentu membutuhkan dana untuk berbagai sarana dan prasarana pendukung. Dari hasil wawancara di atas dapat dijelaskan bahwa ketersediaan dana untuk mendukung kebijakan Karantina Tumbuhan masih tergolong kurang memadai, padahal banyak hal yang harus dilakukan agar kebijakan Karantina Tumbuhan benar-benar dapat dilaksanakan. Teknologi yang digunakan perlu dibenahi agar proses karantina dapat berjalan dengan baik dan lancar, dan untuk teknologi yang dibutuhkan memerlukan dana yang relatif besar untuk pengadaannya di Balai Besar Karantina Pertanian Belawan. Dengan teknologi yang ada saat ini proses operasional dapat saja berjalan lambat, sehingga dengan teknologi yang ada pelayanan masyarakat pengguna jasa belum dapat sepenuhnya ditingkatkan.

Disposisi. Disposisi merupakan gambaran atas sifat pribadi yang terdapat pada implementor. Semakin baik sifat-sifat pribadi maka proses implementasi kebijakan akan semakin lancar. Demikian juga dalam proses implementasi Karantina Tumbuhan membutuhkan implementor yang benar-benar dapat menunjukkan sifat-sifat yang terkendali dalam arti dapat mendukung dilakukannya proses implementasi. Sifat-sifat pribadi dalam penelitian ini adalah tanggung jawab dan komitmen, sebagaimana akan dibahas berikut ini.

Tanggungjawab.

Tanggungjawab merupakan sifat pribadi bagaimana seseorang merasa berkewajiban untuk mewujudkan suatu tujuan, yang dalam penelitian ini adalah mewujudkan penerapan Karantina Tumbuhan. Dari hasil wawancara, dapat dijelaskan bahwa seluruh jajaran instansi merasa bahwa tugas implementasi kebijakan Karantina Tumbuhan dibebankan sebagai tanggungjawab mereka bersama. Walaupun tingkat tanggungjawab pegawai berbeda-beda sesuai dengan bidang tugasnya, tetapi semua pegawai menyadari bahwa mereka merupakan satu kesatuan yang harus bertanggungjawab dalam implementasi kebijakan Karantina Tumbuhan. Dengan demikian dapat dijelaskan bahwa rasa tanggungjawab pegawai telah memadai sehingga cukup mendukung proses impelementasi UU No. 21 Tahun 2019 dalam meningkatkan pelayanan karantina tumbuhan pada Balai Besar Karantina Pertanian Belawan.

Komitmen. Komitmen sebagai sifat implementor merupakan keinginan atau kemauan untuk melaksanakan kebijakan Karantina Tumbuhan sebagaimana dinyatakan dalam UU No. 21 Tahun 2019.

Dari hasil wawancara, dapat dijelaskan bahwa komitmen pegawai terhadap implementasi Karantina Tumbuhan cukup tinggi, terlihat dari kesungguhan mereka melakukan pembahasan atas berbagai rencana yang diperlukan untuk menerapkan kebijakan tersebut. Terdapat keyakinan bersama bahwa dengan implementasi Karantina Tumbuhan 
maka pekerjaan akan lebih mudah dilaksanakan, sehingga harus segera diwujudkan. Dengan demikian dapat disimpulkan bahwa komitmen pegawai telah cukup memadai sehingga cukup mendukung proses impelementasi UU No. 21 Tahun 2019 dalam meningkatkan pelayanan karantina tumbuhan pada Balai Besar Karantina Pertanian Belawan.

Struktur Birokrasi. Struktur birokrasi terdiri dari unit-unit organisasi, struktur dan keterkaitan atau hubungan antara fungsi, yang secara jelas dapat dilihat dalam struktur organisasi dan uraian tugasnya. Indikator yang digunakan untuk mengetahui struktur birokrasi tersebut adalah: pembagian tugas dan pelaksanaan fungsi koordinasi.

Pembagian Tugas. Pentingnya pembagian tugas dalam struktur organisasi dalam implementasi Karantina Tumbuhan akan memperjelas siapa yang bertanggungjawab melaksanakan dan serta tidak menimbulkan salah penafsiran.

Dari hasil wawancara, dapat dijelaskan bahwa pembagian tugas telah dilakukan dengan baik dengan menyerahkan setiap pekerjaan kepada unit yang memiliki keahlian dalam pelaksanaan tugas tersebut. Pembagian tugas juga dilakukan dengan memperhatikan beban kerja pada setiap unit organisasi. Artinya beban kerja harus sebanding dengan kapasitas pegawai yang ada pada setiap unit. Dengan demikian bahwa pembagian tugas pada instansi telah memadai sehingga cukup mendukung proses impelementasi UU No. 21 Tahun 2019 dalam meningkatkan pelayanan karantina tumbuhan pada Balai Besar Karantina Pertanian Belawan.

Pembagian tugas juga harus dilakukan dengan jelas agar tidak berakibat pada timpang tindihnya pelaksanaan pekerjaan. Dengan demikian kebijakan yang ditetapkan sebagai dasar pembagian tugas juga harus jelas dalam arti tidak menimbulkan penafsiran yang berbeda antara pegawai. Penafsiran yang berbeda atas kebijakan bisa saja terjadi, tetapi hal tersebut tidak menimbulkan gangguan terhadap pembagian tugas. Artinya bahwa walaupun terdapat penafsiran yang berbeda terhadap isi kebijakan, perbedaan tersebut dapat diatasi melalui proses pembahasan bersama. Dengan demikian dapat disimpulkan bahwa penyelesaian perbedaan penafsiran atas kebijakan telah cukup memadai sehingga cukup mendukung proses impelementasi UU No. 21 Tahun 2019 dalam meningkatkan pelayanan karantina tumbuhan pada Balai Besar Karantina Pertanian Belawan.

Koordinasi. Koordinasi yang baik dapat mengendalikan semua proses yang dilakukan secara terpisah agar menjadi lebih terpadu. Koordinasi kegaitan dalam proses implementasi kebijakan Karantina Tumbuhan juga penting, agar semua pegawai melakukan segala upaya untuk mewujudkan pelaksanaan kebijakan.

Dari hasil wawancara di atas dapat dijelaskan bahwa pimpinan setiap unit dapat melakukan koordinasi dengan unit lain sesuai dengan kepentingan masing-masing. Koordinasi dapat berlangsung secara formal melalui prosedur kerja yang telah ditetapkan. Namun demikian koordinasi juga dapat dilakukan secara formal untuk hal-hal yang tidak diatur secara formal. Dengan demikian pelaksanaan koordinasi pada instansi telah memadai sehingga cukup mendukung proses impelementasi UU No. 21 Tahun 2019 dalam meningkatkan pelayanan karantina tumbuhan pada Balai Besar Karantina Pertanian Belawan.

\section{Faktor Kendala Implementasi Undang- Undang No. 21 Tahun 2019 tentang Karantina Hewan, Ikan, dan Tumbuhan Pada Balai Besar Karantina Pertanian Belawan}

Terbitnya UU No. 21 Tahun 2019 ditujukan untuk meningkatkan pelayanan terhadap masyarakat pengguna jasa karantina, termasuk juga karantina tumbuhan. Tetapi sampai saat ini proses operasional karantina tumbuhan belum dapat memuaskan bagi masyarakat, yang berarti implementasi UU tersebut belum sepenuhnya berhasil dilaksanakan. Hal ini disebabkan adanya beberapa faktor kendala dalam impelementasi, sebagaimana diuraikan sebagai berikut:

Ketersediaan Dana Kurang Memadai. Ketersediaan dana untuk mendukung kebijakan Karantina Tumbuhan masih tergolong kurang memadai, padahal banyak hal yang harus dilakukan agar kebijakan Karantina Tumbuhan benar-benar dapat dilaksanakan. Teknologi yang digunakan sudah ketinggalan zaman padahal sebenarnya teknologi yang lebih baik dalam proses karantina sudah tersedia, tetapi membutuhkan dana yang relatif besar untuk pengadaannya di Balai Besar 
Karantina Pertanian Belawan. Dengan teknologi yang ada saat ini maka proses operasional berjalan lambat, sehingga dengan teknologi yang ada pelayanan masyarakat pengguna jasa belum dapat sepenuhnya ditingkatkan. Dengan demikian pengadaan teknologi berupaya untuk proses karantina tumbuhan masih belum tersedia, sehingga tidak mendukung proses impelementasi UU No. 21 Tahun 2019 dalam meningkatkan pelayanan karantina tumbuhan pada Balai Besar Karantina Pertanian Belawan. Untuk mengatasi masalah tersebut maka sebaiknya instansi perlu mengajukan anggaran kepada pemerintah (Pusat) agar dapat memenuhi kebutuhan pengadaan teknologi yang lebih baik dalam proses operasional karantina tumbuhan, sehingga pelayanan kepada masyarakat pengguna jasa dapat ditingkatkan.

Integritas Pegawai. Masih ada kemungkinan beberapa pegawai yang perilaku nya tidak mempunyai tanggungjawab atas pekerjaan yang di berikan kepadanya. karena bagaimanapun tidak memungkinkan bagi pimpinan untuk mengawasi secara seksama semua tindakan petugas yang berhubungan langsung dengan pihak eksternal. Dengan demikian dapat disimpulkan bahwa integritas pegawai masih tergolong kurang sehingga untuk mendukung proses impelementasi UU No. 21 Tahun 2019 dalam meningkatkan pelayanan karantina tumbuhan pada Balai Besar Karantina Pertanian Belawan belum terlaksana dengan baik dan lancar.

Petugas Kurang Tanggap Menangani Keluhan. Petugas pada Balai Besar Karantina Pertanian Belawan belum memiliki kompetensi yang baik dalam penanganan keluhan dengan baik. Dalam hal ini banyak masyarakat pengguna jasa yang merasa kecewa karena petugas tidak dapat dengan segera menanggapi keluhannya padahal sudah menunggu seharian di kantor. Alasannya dikarenakan kurang nya petugas (pegawai) yang ada di Balai Besar Karantina Pertanian Belawan.

\section{SIMPULAN}

Implementasi UU No. 21 Tahun 2019 pada Balai Besar Karantina Pertanian Belawan sudah diterapkan namun belum terlaksana dengan optimal, hal ini dapat dilihat dari hasil analisis indikator: Dari segi Komunikasi implementasi UU No. 21 Tahun 2019 dalam rangka peningkatan pelayanan Karantina
Tumbuhan pada Balai Besar Karantina Pertanian Belawan, sudah berjalan dengan baik. Dari segi sumber daya, implementasi belum berjalan dengan baik karena petugas kurang memiliki kompetensi yang baik dalam penanganan keluhan, kurangnya pegawai serta kurangnya ketersediaan dana untuk pengadaan teknologi yang dibutuhkan dalam peningkatan operasional pelayanan karantina tumbuhan. Dari segi disposisi, implementasi belum berjalan dengan baik. Hal ini disebabkan pegawai kurang memenuhi tanggungjawab pekerjaannya jika dibanding dengan tanggungjawab pribadi. Dari segi struktur birokrasi, implementasi sudah berjalan dengan baik. Kendala yang dihadapi instansi dalam implementasi Karantina Tumbuhan adalah: ketersediaan dana anggaran yang kurang memadai untuk pengadaan teknologi yang dapat mempercepat proses pelayanan karantina, kurangnya integritas pegawai, petugas kurang tanggap menangani keluhan masyarakat pengguna jasa, serta tanggungjawab pegawai terhadap pekerjaan masih kurang memadai karena lebih mengutamakan kepentingan pribadi.

\section{DAFTAR PUSTAKA}

Izmi, D., Yulaicho, M., \& Nawangsari, E. (2021). Implementasi Kebijakan Program Komando Strategis Pembangunan Pertanian (Kostratani) di Kecamatan Sukodono Kabupaten Sidoarjo. Journal of Education, Humaniora and Social Sciences (JEHSS), 4(2), 702-710. doi:https://doi.org/10.34007/jehss.v4i2.729

Munif, A. (2012). Perspektif dan Inisiatif Pengembangan Perlakuan Karantina Tumbuhan. Bogor: Istitut Pertanian Bogor.

Nugroho, A.D. Waluyati, L.R. \& Jamhari (2018). Upaya Memikat Generasi Muda Bekerja pada Sektor Pertanian di Daerah Istimewa Yogyakarta. JPPUMA: JPPUMA: Jurnal Ilmu Pemerintahan dan Sosial Politik UMA (Journal of Governance and Political UMA), 6 (1): 76-95.

Purba, K. (2015). Pengawasan dan Karantina terhadap Tumbuhan dan Hewan Pada Balai Besar Karantina Tumbuhan dan Hewan Belawan, Medan: Universitas Sumatera Utara.

Ristiyawan, B. (2013). Peranan Implementasi Kebijakan Karantina Ikan dalam Pembangunan Perikananan Berkelanjutan. Prosiding Seminar Nasional Pengelolaan Sumberdaya Alam dan Lingkungan, Semarang: Universitas Diponegoro. 
Hotma Diana Siregar, Maksum Syahri Lubis \& Adam, Implementasi Undang-Undang Nomor 21 Tahun

Siagian, R., Pakpahan, K., \& Akbar, F. (2020). Mekanisme Persyaratan Teknik Perizinan Pemasukan Benih Tumbuhan dari Luar Negeri ke Sumatera Utara. Journal of Education, Humaniora and Social Sciences (JEHSS), 3(1), 241-251. doi:https://doi.org/10.34007/jehss.v3i1.289

Silaban, L.R. dan Sugiharto, (2016) Usaha Usaha yang Dilakukan Pemerintah dalam Pembangunan Sektor Pertanian, JPPUMA: Jurnal Ilmu Pemerintahan dan Sosial Politik UMA (Journal of Governance and Political UMA), 4 (2): 196-210.

Suartono, G.N. (2016). Kualitas Pelayanan Karantina Hewan pada Kantor Balai Karantina Pertanian Kelas II Palu. e-Jurnal Katalogis, $4(1)$.

Sugiyono. (2012). Metode Penelitian Kuantitatif, Kualitatifdan R\&D. Bandung: Alfabeta.
Suharyanto, A. Harianja, R.S.H.K. Ndraha, P.W. Saragih, I.S.K. Sipayung, K.F. Harahap, N. \& Nababan, R. D. (2019). Indigenous Knowledge Masyarakat Etnis Karo Terhadap Pengelolaan Tumbuhan Hutan Di Desa Lingga, Kabupaten Karo. Journal of Education, Humaniora and Social Sciences (JEHSS). 1 (3): 162-169.

Suyatno, B. (2010). Metode Penelitian Kualitatif. Jakarta: Masmedia.

Undang-Undang No. 21 Tahun 2019 tentang Karantina Hewan, Ikan, dan Tumbuhan pada Balai Besar Karantina Pertanian Belawan.

Zubaedah, N. (2015). Keefektifan Kebijakan Pembatasan Pintu Masuk Impor Hortikultura terhadap Aspek Perlindungan Tanaman. Risalah Kebijakan Pertanian dan Lingkungan Vol. 2 No. 2. 